\title{
Review
}

\section{Planned Pregnancy in Kidney Transplantation. A Calculated Risk}

\author{
Claudio Ponticelli ${ }^{1, *}+{ }^{(D}$, Barbara Zaina ${ }^{2}$ and Gabriella Moroni $^{3}$ \\ 1 Nephrology, Ospedale Maggiore Policlinico, 20122 Milan, Italy \\ 2 Department of Obstetrics and Gynecology, IRCCS Ca' Granda Ospedale Maggiore Policlinico, \\ 20122 Milan, Italy; barbara.zaina@policlinico.mi.it \\ 3 Department of Biomedical Sciences, IRCCS Humanitas Research Hospital, Humanitas University, \\ 20122 Milan, Italy; gabriella.moroni@hunimed.eu \\ * Correspondence: ponticelli.claudio@gmail.com \\ + Retired.
}

check for

updates

Citation: Ponticelli, C.; Zaina, B.; Moroni, G. Planned Pregnancy in Kidney Transplantation. A Calculated Risk. J. Pers. Med. 2021, 11, 956. https://doi.org/10.3390/jpm11100956

Academic Editor: Franco Citterio

Received: 12 August 2021

Accepted: 23 September 2021

Published: 26 September 2021

Publisher's Note: MDPI stays neutral with regard to jurisdictional claims in published maps and institutional affiliations.

Copyright: (C) 2021 by the authors. Licensee MDPI, Basel, Switzerland. This article is an open access article distributed under the terms and conditions of the Creative Commons Attribution (CC BY) license (https:// creativecommons.org/licenses/by/ $4.0 /)$.

\begin{abstract}
Pregnancy is not contraindicated in kidney transplant women but entails risks of maternal and fetal complications. Three main conditions can influence the outcome of pregnancy in transplant women: preconception counseling, maternal medical management, and correct use of drugs to prevent fetal toxicity. Preconception counseling is needed to prevent the risks of an unplanned untimely pregnancy. Pregnancy should be planned $\geq 2$ years after transplantation. The candidate for pregnancy should have normal blood pressure, stable serum creatinine $<1.5 \mathrm{mg} / \mathrm{dL}$, and proteinuria $<500 \mathrm{mg} / 24 \mathrm{~h}$. Maternal medical management is critical for early detection and treatment of complications such as hypertension, preeclampsia, thrombotic microangiopathy, graft dysfunction, gestational diabetes, and infection. These adverse outcomes are strongly related to the degree of kidney dysfunction. A major issue is represented by the potential fetotoxicity of drugs. Moderate doses of glucocorticoids, azathioprine, and mTOR inhibitors are relatively safe. Calcineurin inhibitors (CNIs) are not associated with teratogenicity but may increase the risk of low birth weight. Rituximab and eculizumab should be used in pregnancy only if the benefits outweigh the risk for the fetus. Renin-angiotensin system inhibitors, mycophenolate, bortezomib, and cyclophosphamide can lead to fetal toxicity and should not be prescribed to pregnant women.
\end{abstract}

Keywords: posttransplant pregnancy; fetotoxicity; eclampsia; immunosuppression

\section{Introduction}

In most women with successful kidney transplantation, fertility is spontaneously restored within a few months, resulting in normal ovulatory cycles and regular menstruation [1-3]. This offers a chance for transplanted women to have children. Pregnancy can be a reasonable option for women with a good function of the kidney transplant. However, pregnancy in transplanted patients remains high risk [4]. A meta-analysis and systematic review of 6712 pregnancies in 4174 kidney transplant recipients reported that the live-birth rate was $72.9 \%$. The other pregnancy outcomes were complicated by cesarean section $(62.6 \%)$, preterm delivery $(43.1 \%)$, pregnancy-induced hypertension $(24.1 \%)$, preeclampsia $(21.5 \%)$, miscarriages $(15.4 \%)$, induced abortions $(12.4 \%)$, gestational diabetes $(5.7 \%)$, stillbirths (5.1\%), and ectopic pregnancies (2.4\%) [5].

In this article, the main potential issues of pregnancy in kidney transplantation will be discussed. Particular attention will be focused on three main topics: the counseling on contraception, the maternal medical management during pregnancy, and the choice of immunosuppressive drugs to prevent fetal toxicity.

\section{Planning Posttransplant Pregnancy}

Pregnancy leads to physiologic changes in kidney and systemic hemodynamics that cause important alterations in acid-base, electrolyte, and kidney function. Glomerular 
hyperfiltration occurs during pregnancy. An increase in $24 \mathrm{~h}$ creatinine clearance by $25 \%$ occurs in the first 4 weeks after the last menstrual period and by $45 \%$ at 9 weeks. During the third trimester, there is some decrease in creatinine clearance with a small increase in the first days of puerperium. An increase in plasma uric acid concentration in pregnancy may predict the development of preeclampsia. Proteinuria may develop in almost $40 \%$ of patients near term but disappears after delivery. Transient diabetes insipidus may occur late in pregnancy. It disappears with puerperium but may be responsible for hypovolemia and electrolyte unbalance [6]. Understanding these changes is essential when evaluating pregnant women with kidney transplantation, outlining that transplanted pregnant women should be closely monitored and followed by a team of expert nephrologists and gynecologists.

The potential issues of pregnancy should be discussed, preferably prior to transplantation, by women and their partners with a multidisciplinary team of expert nephrologists and obstetricians. Such issues include preconception counseling, knowledge of factors that may affect pregnancy success, the timing of pregnancy, and the possible impact of medical management on maternal and fetal outcomes $[7,8]$.

Early counseling on contraception is important to reduce the risk of unplanned pregnancies, improve pregnancy outcomes, and reduce maternal complications. Hormonal methods may be safe in women with stable graft function but are not recommended in women with hypertension or risk of thrombosis. Indeed, arterial hypertension during pregnancy is associated with increased arterial thrombotic risk [9]. All combined oral contraceptives investigated in an analysis were associated with an increased risk of venous thrombosis; the effect size depended both on the progestogen used and the dose of ethinylestradiol [10]. Intrauterine devices, oral contraceptives, and subdermal implants have been shown to have great efficacy as well as low systemic drug absorption, allowing clinicians to provide a vast range of options to transplant women in their childbearing years [11-13]. Counseling should be repeated after transplantation [14]. Emergency contraception with high dose progestins or intrauterine devices is not contraindicated, but it should be avoided whenever possible, even if far preferable to abortion [15].

Several factors may affect pregnancy outcomes, including rejection, poor graft function, nephrotic syndrome, hypertension, obesity, diabetes, and infections. According to the National Transplantation Pregnancy Registry (NTPR), the ideal candidate for posttransplant pregnancy should not have had rejection in the last year, should have adequate and stable kidney graft function (serum creatinine $<1.5 \mathrm{mg} / \mathrm{dl}$ and protein exception $<$ $500 \mathrm{mg} / 24 \mathrm{~h}$ urine protein excretion), normal blood pressure (with or without therapy), and stable immunosuppression [8]. She should not suffer from comorbid factors that may worsen pregnancy outcomes, such as chronic allograft dysfunction, cardiopulmonary diseases, severe hypertension, diabetes mellitus, nephrotic proteinuria, morbid obesity, maternal infection with hepatitis B or $\mathrm{C}$, and severe liver failure.

The timing of conception may depend on the characteristics of the patient. The NTPR suggested that a patient can safely proceed with the pregnancy, independently of the date of transplant, if graft function is optimal [8]. However, it can be unsafe to plan conception early after transplantation. The peritransplant period is a time of the highest use of potentially fetotoxic or teratogenic medications and a time when optimization of immunosuppression is essential to prevent rejection [16]. A retrospective study of 729 pregnancies revealed an increased risk of death-censored graft loss during the first and second year after transplantation (hazard ratio 1.25 and 1.26, respectively), while pregnancy in the third year was no longer associated with an increased risk of graft failure [17]. Thus, it is safer to plan pregnancy at least 2 years after transplantation [18-20].

The patient should be vaccinated before pregnancy. Most live attenuated vaccines are contraindicated after transplantation. Thus, women who are not immune to rubella should receive the rubella vaccine before transplantation. However, there are emerging safety profile and efficacy data to support the use of specific live attenuated vaccines. In the posttransplant setting, inactivated vaccines can be administered starting at 3 months post- 
transplant, except for influenza, which can be given as early as one month. Close contacts of transplant patients can receive most routine live vaccines, including pneumococcal, influenza, hepatitis B, human papilloma virus, and meningococcal vaccines. In general, vaccines are recommended more than two weeks prior to transplantation, or starting at 1-6 months after transplantation [21]. Of particular concern is coronavirus disease 2019 (COVID-19) which is associated with a high rate of hospitalization and admission to intensive care units in kidney transplant recipients [22-25]. Since persons on immunosuppressive medications are at increased risk for severe COVID-19, it is recommended that those people may receive a COVID-19 vaccine along with counseling that the vaccine safety and efficacy profiles are unknown, and there is a potential for reduced immune responses [26].

\section{Maternal Medical Management and Outcomes during Pregnancy}

The aims of the treatment are to maintain alloimmunity quiescence during and after pregnancy and to improve the outcome of the fetus. Reaching these goals largely depends on the conditions of the patient at conception. Besides the recommendations reported above, pregnancy should be avoided in women with acute rejection in the last 12 months before conception and in patients with impaired graft function. In pregnant women with various stages of CKD, the risk of adverse outcome increased from $34 \%$ to $90 \%$ from stage 1 to 4 [27]. In many cases, prematurity and low birth weight are caused by obstetric management to favor early delivery in patients with severe CKD or preeclampsia. In these cases, it is difficult to balance the interest of the pregnant woman and her fetus. Some authors have proposed that maternal autonomy should be the dominant concern in decision making, whereas others have established the fetus as a patient who should be treated according to the principles of beneficence.

The most frequent maternal risks include infection, hypertension, preeclampsia, gestational diabetes, and acute rejection (Table 1).

Table 1. Main maternal adverse events during pregnancy after kidney transplantation.

\begin{tabular}{|c|c|c|}
\hline Complication & Incidence & Consequences \\
\hline Infection & $\begin{array}{l}\text { Very common. Urinary tract infection } \\
\text { (often asymptomatic) may affect most } \\
\text { transplant women. }\end{array}$ & $\begin{array}{l}\text { Urinary tract infections can increase the risk of } \\
\text { preeclampsia. Pyelonephritis is an uncommon but } \\
\text { severe complication. The risk of viral infection is } \\
\text { elevated in case of early pregnancy. Infection may } \\
\text { lead to graft dysfunction. }\end{array}$ \\
\hline Hypertension & $\begin{array}{l}\text { Many transplanted women are already } \\
\text { hypertensive before pregnancy. }\end{array}$ & $\begin{array}{l}\text { Hypertension can predispose to preeclampsia and } \\
\text { is a main risk factor for cardiovascular disease, } \\
\text { cerebrovascular disease, and graft dysfunction. }\end{array}$ \\
\hline Preeclampsia & $\begin{array}{l}\text { The incidence is higher in patients with } \\
\text { poor graft function or hypertension. }\end{array}$ & $\begin{array}{c}\text { Preeclampsia may result in damage to the kidneys, } \\
\text { liver, lung, heart, or eyes, and may cause a stroke } \\
\text { or other brain injury. }\end{array}$ \\
\hline Gestational diabetes mellitus & About $16 \%$ & $\begin{array}{l}\text { A maternal and neonate risk factor of adverse } \\
\text { events during pregnancy. }\end{array}$ \\
\hline Acute rejection & About $10 \%$ & $\begin{array}{l}\text { Risk factor for graft dysfunction. Infection may } \\
\text { develop after aggressive } \\
\text { immunosuppressive treatment. }\end{array}$ \\
\hline
\end{tabular}

\subsection{Infection}

The placental immune response and its tropism for specific viruses and pathogens affect the outcome of the pregnant woman's susceptibility to and severity of certain infectious diseases [28]. Prophylaxis and treatment of bacterial and viral infections are important in pregnant transplant recipients. These patients are at increased risk of infections, especially bacterial urinary tract infections and acute pyelonephritis of the graft. Urine cultures 
should be performed monthly and all asymptomatic infections should be treated. Whether urinary tract infection impacts on graft and patient survival is still uncertain [29]. A metaanalysis in nontransplanted pregnant women reported that urinary tract infection during pregnancy increases the risk of preeclampsia [30]. Antibiotic prophylaxis for all surgical procedures is recommended. The risk of cytomegalovirus (CMV) infection during pregnancy is low in transplant women, since pregnancy is usually planned 1-2 years after transplantation. However, monitoring of CMV infections is recommended, because congenital CMV is the main nongenetic cause of congenital sensorineural hearing loss and neurological damage [31].

\subsection{Hypertension}

Pregnancy hypertension is defined as systolic blood pressure $\geq 140 \mathrm{~mm} \mathrm{Hg}$ or diastolic blood pressure $\geq 90 \mathrm{~mm} \mathrm{Hg}$. About 70-90\% of kidney transplant recipients have either arterial hypertension or require antihypertensive therapy $[32,33]$. Posttransplant hypertension is an independent risk factor for pregnancy complications [34,35]. There is no definite indication for treatment of mild-moderate hypertension in pregnancy. However, when mean arterial pressure exceeds $140 \mathrm{mmHg}$ (equivalent to 180), there is a significant risk of maternal cerebral vascular damage. Oral labetalol and methyldopa are most used, and second-line agents include clonidine and calcium channel blockers $[36,37]$. Both angiotensin-converting enzyme inhibitors (ACE-Is) and angiotensin receptor blockers (ARBs) are contraindicated in pregnancy because single-center reports and meta-analyses revealed a significant association between overall congenital malformations and first trimester exposure to ACEI/ARBs. Cardiovascular malformations, miscarriage, and stillbirth also had a significant relation with ACEI/ARB exposure [38,39].

\subsection{Preeclampsia}

In transplanted women, pregnancies remain high risk with an increased prevalence of preeclampsia. A Norwegian retrospective cohort study based on 1,272,000 deliveries reported an adjusted incidence rate ratio of 6.06 [40]. Preeclampsia is caused by placental and maternal vascular dysfunction and should not be confused with cases of de novo hypertension or proteinuria [41]. Today, preeclampsia is considered a systemic disease with widespread endothelial damage and the potential to affect future cardiovascular diseases rather than a self-limited occurrence. Underlying mechanism(s) include heme oxygenase and hydrogen sulfide pathways, autoantibodies, misfolded proteins, nitric oxide, oxidative stress, extracellular vesicles containing miRNA, and other important nucleotides [42,43]. These mechanisms can result in abnormal placentation, inadequate spiral artery remodeling, deficiency in trophoblast invasion, reduced maternal blood flow to the placenta, and a release of signals and/or inflammatory mediators into maternal circulation, triggering the systemic manifestations of preeclampsia. The risk of preeclampsia in pregnant transplant women might be related to poor graft function, hypertension, and immunosuppressive therapy. In pregnant women, glucocorticoids may cause adverse events that are mainly related to their dosage and duration, but whether the use of glucocorticoids can increase the risk of preeclampsia is still uncertain. In pregnant patients with autoimmune disease taking glucocorticoids, confounding factors, including the dosage of prednisone and the nature and severity of the underlying autoimmune disease, were not detailed [44-46]. The only study that adjusted for disease and disease severity did not find evidence of an association between prednisone use and preeclampsia [47]. Hypertension and preeclampsia have been reported to occur at higher incidence in transplanted women taking calcineurin inhibitors $[48,49]$. A systematic review and meta-analysis could not find any difference in the rate of preeclampsia between transplant pregnant women taking cyclosporine or tacrolimus [50].

Signs and symptoms of preeclampsia include hypertension, proteinuria, diffuse edema, belly pain in the upper right side, gastric troubles, and vision changes. In a study from Norway, transplant women with preeclampsia had significantly higher postpar- 
tum serum creatinine levels, higher risks of preterm delivery, cesarean delivery, and small for gestational age infants. In the final multivariate model, chronic hypertension, previous preeclampsia, and elevated serum creatinine at the start of pregnancy were prognostic factors for preeclampsia [51]. In the most severe forms, preeclampsia can lead to eclampsia, defined as the new onset of generalized tonic-clonic seizures. Eclampsia is a life-threatening condition for the mother and fetus. The early treatment of acute hypertension, use of magnesium sulfate, and early hospitalization may prevent the development of eclampsia, but the only effective treatment is delivery. Although preeclampsia has not been found to have a deleterious effect on kidney graft function in transplant women, it can cause premature delivery $[52,53]$. The drug of choice to treat and prevent eclampsia is magnesium sulfate. Intravenous magnesium sulfate should be the initial drug administered to terminate seizures. A loading dose of $4 \mathrm{mg}$ (15-20 $\mathrm{min}$ ) and a maintenance dose of 1-2 g per hour as a continuous intravenous solution should be administered [54]. Management of severe hypertension $(\geq 170 / 110 \mathrm{~mm} \mathrm{Hg}$ ) may include intravenous hydralazine or labetalol. Oral nifedipine may be an alternative treatment. Blood pressure should not be excessively decreased to prevent inadequate uteroplacental perfusion and fetal compromise. The goal is to maintain systolic blood pressure between 140 and $160 \mathrm{~mm} \mathrm{Hg}$ and diastolic blood pressure around $90-110 \mathrm{~mm} \mathrm{Hg}$. Since a preterm delivery is required in women with eclampsia, a single course with betamethasone (12 mg IM q24h $\times 2$ doses) may be administered for acceleration of fetal lung maturity. A systematic review and meta-analysis reported that antenatal steroids at $\geq 34$ weeks' gestation can reduce neonatal respiratory morbidity [55]

\subsection{Thrombotic Microangiopathy}

This complication, also called atypical hemolytic-uremic syndrome (HUS), is a medical emergency that may complicate the course of pregnancy or postpartum period. Thrombotic microangiopathy is characterized by microangiopathic hemolytic anemia, thrombocytopenia, and acute kidney injury. Its presentation is like preeclampsia. The differential diagnosis can be challenging [56]. Unfortunately, delays in appropriate diagnosis and treatment may be life-threatening. An international multidisciplinary working group proposed an approach that considers the timing of events in pregnancy or postpartum, coexisting symptoms, first-line laboratory workup, and probability-based assessment of possible causes of pregnancy-associated thrombotic microangiopathy. Deficiency of a disintegrin and metalloproteinase with thrombospondin-1 motifs (ADAMS13, a 13 member of the family) may diagnose a thrombotic thrombocytopenic purpura. Complement alternative pathway dysregulation indicates a diagnosis of atypical HUS [57]. Plasma exchanges and eculizumab are the first-line treatments for atypical HUS [58,59].

\subsection{Kidney Dysfunction}

Apart from pregnancy-related complications, other events may be responsible for graft function deterioration, including symptomatic or silent rejection, recurrence or de novo glomerular disease, and drug-related nephrotoxicity. Serum creatinine and proteinuria should be closely monitored in posttransplant pregnancy. Due to the physiologic alterations of kidney function induced by pregnancy, the baseline serum creatinine value should be that measured 4 weeks after conception, which is lower than that measured before pregnancy. A comprehensive analysis of various worldwide registers reported that the overall acute rejection rate during pregnancy among 822 kidney transplant recipients was $9.4 \%$ [5]. In some cases, rejection is not associated with signs and symptoms other than a mild increase in serum creatinine. In difficult cases, kidney biopsy is a reasonable option [60]. In cases of acute rejection, steroids and/or anti-thymocyte globulins (ATGs) are the preferred drugs. It should be noted that the trough blood levels of tacrolimus and, importantly, cyclosporine tend to decline at the second trimester [61]. Some investigators prefer to increase the doses of CNI, but the is no evidence that lower blood levels reflect the intracellular concentration of CNI [62]. 
Fetal complications are more frequent in women with poor graft function. A retrospective study estimated the effects of pregnancy renal function on pregnancy outcome. For women with serum creatinine $<1.4 \mathrm{~m} / \mathrm{dL}$, fetal growth restriction occurred in $25 \%$ of cases, preterm delivery in $30 \%$, preeclampsia in $22 \%$, and perinatal deaths in $1 \%$. If serum creatinine was $\geq 2 \mathrm{mg} / \mathrm{dL}$, fetal growth restriction occurred in $65 \%$ of cases, preterm delivery in $>90 \%$, preeclampsia in $60 \%$, and perinatal deaths in $10 \%$ [63].

\subsection{Diabetes Mellitus}

During pregnancy, some women display metabolic abnormalities like those of people with type 2 diabetes mellitus, such as insulin resistance and reduced $\beta$-cell compensation for that resistance. This gestational diabetes may be defined as an increase in the fasting plasma glucose level of $6.9 \mathrm{mg} / \mathrm{dL}$, an increase in the $1 \mathrm{~h}$ plasma glucose level of $30.9 \mathrm{mg} / \mathrm{dL}$, and an increase in the $2 \mathrm{~h}$ plasma glucose level of $23.5 \mathrm{mg} / \mathrm{dL}$ [64]. In kidney transplant recipients, gestational diabetes develops in $16 \%$ of pregnancies [65]. A systematic review and meta-analysis did not find a significant difference in the incidence of gestational diabetes between tacrolimus- and cyclosporine-treated transplant pregnancies [46]. Several studies in nontransplant women reported that gestational diabetes is associated with adverse pregnancy outcome $[66,67]$. All women with gestational diabetes mellitus should receive nutritional counseling, be instructed in self-monitoring of blood glucose, and should increase physical activity to moderate intensity levels if not contraindicated. The treatment goal is to maintain fasting blood glucose levels $<95 \mathrm{mg}$ per $\mathrm{dL}$ and $1 \mathrm{~h}$ postprandial $<140 \mathrm{mg} / \mathrm{dL}$. About $15-30 \%$ of patients who do not meet these goals should begin insulin therapy [68].

In summary, despite the risk of several complications, single-center and registry reports [69-74] and a meta-analysis [75] found that pregnancies in kidney transplant recipients with normal kidney function did not affect short-term and long-term patient and graft survival. However, the risk of graft dysfunction during pregnancy or in the postpartum period may be elevated in patients who became pregnant early after transplantation [14-17] and in those with elevated levels of serum creatinine [76,77]. A word of caution may concern the long-term impact on a patient who develops preeclampsia. A systematic review and meta-analysis in nontransplant women reported that preeclampsia significantly increases the risk of end-stage renal disease [78].

\section{Immunosuppressive Drugs and Fetal Outcome}

A major issue is represented by the potential teratogenic or toxic effects on the fetus (Table 2). The immunosuppressive agents more frequently used in kidney transplantation may be divided into three main categories: drugs that are relatively safe, new drugs with uncertain safety, and drugs with moderate to high fetal risk (Table 2).

Table 2. Potential teratogenic effects of immunosuppressive drugs.

Glucocorticoids (GC)

GC can cross the placenta but are metabolized by $11 \beta-$ HSD2 to inactive products with the exception of dexamethasone and

betamethasone. Fetal toxicity cannot be ruled out (Class $\mathrm{C}$ according to FDA).
Minimal risk of oral-facial cleft. It is unlikely that moderate doses of GC lead to fetal

hypothalamic-pituitary-adrenal axis dysfunction or interfere with the early life programming, since $11 \beta$-hydroxysteroid dehydrogenase 2 is a major barrier against cortisol transfer to the fetus. Concern remains about the fetal toxicity when the mothers receive prolonged treatments with high-dose GC.

CNI metabolites can be seen in the placenta. The CNI maternal-fetal transplacental passage is influenced by the activity of P-glycoprotein that pumps CNI out of the trophoblast cells of placenta and restricts its passage across the placental barrier. CNI are listed in Class C.
The relatively high number of premature births that has been reported may be partially explained by an obstetric policy favoring earlier delivery. Nonetheless, long-term effects in humans prenatally exposed to CNIs require further evaluation. 
Table 2. Cont.

Azathioprine (AZA)
Placenta is a barrier to 6-mercaptopurine the main metabolite of AZA. This explains the lack of teratogenicity of AZA. The FDA classified AZA as a drug at potential risk of teratogenic effects (Class C) based on animal studies.
The risk of congenital anomalies in offspring are similar to those found in general population, but there is a higher incidence of prematurity and lower weight at birth in AZA-treated pregnant women. There is also an increased risk of materno-fetal infections, especially CMV infection. The use of AZA is considered safe.

Women being considered for treatment with MPA should always have a negative pregnancy test. There is an increased risk of pregnancy loss and congenital malformations with the use of MPA during pregnancy. If pregnancy occurs MPA should be stopped. The later MPA is discontinued the higher is the risk of complications.
MPA during pregnancy is associated with an increased risk of congenital malformations. MPA is considered as class D (Evidence of risk to human fetus) by FDA.
Animal reproduction studies have shown an adverse effect on the fetus. There are not adequate and well-controlled studies in humans, but potential benefits may warrant use of the drug in pregnant women despite potential risks; mTORi are considered as class $C$ by FDA.

Data on RTX during pregnancy are scarce. RTX contains an IgG and can cross the placenta. RTX is considered in class C.

There is a selective transport of unbound eculizumab across the placenta. However, the

levels observed in umbilical cord blood samples do not affect the concentrations of complement in newborns.
The mTORi exposure during pregnancy does not appear to be associated with an increased risk or a pattern of birth defects.
The administration of RTX to a pregnant woman is discouraged unless the benefits outweigh the potential risk for the fetus.

The use of eculizumab to pregnant women with paroxysmal hemoglobinuria nocturnal is associated with a high rate of fetal survival and a low rate of maternal complications. Therefore, eculizumab may be regarded as safe in pregnancy.

Anecdotal cases of successful pregnancy with the use of belatacept in transplant women have been reported.

\subsection{Relatively Safe Drugs}

Glucocorticoids easily cross the placenta [79] but are metabolized within the placenta by $11 \beta$-hydroxysteroid dehydrogenase- 2 (11ß-HSD2) which converts cortisol and synthetic glucocorticoids into inactive products $[80,81]$. A short course of poorly metabolized betamethasone can be used to prevent fetal respiratory distress in selected cases. Only excessive glucocorticoid administration can influence fetal growth [82-84] and results in dysfunction of the fetal hypothalamic-pituitary-adrenal axis [85]. This phenomenon, termed early life programming, may be associated in the long-term with impaired brain growth and increased susceptibility to cardiovascular disease. However, since only $3 \%$ of maternal cortisol is transferred to the fetal circulation [86], it is unlikely that moderate doses of exogenous glucocorticoids may interfere with the early life programming, unless there are alterations of $11 \beta-H S D 2$ activities, as in the case of preeclampsia [87]. There has been concern about a possible increase in oral-facial clefts in newborns from mothers receiving glucocorticoids. This risk is 1.3 to 3.3 for every 1000 pregnancies exposed to glucocorticoids versus a birth population prevalence of 1 per 1000 [88]. Further studies confirmed that the risk of oral-facial cleft associated with prenatal exposure to glucocorticoids is minimal [89].

Calcineurin inhibitors. Reduced fetal weight, low birth weight and skeletal retardation, cesarean delivery, and hypertensive disorders of pregnancy have been frequently reported in pregnant transplanted women given CNIs [90]. However, transplant recipients are 
treated with many drugs, including other immunosuppressant agents, that may lead to confounding results. CNIs can cross the placenta [91]. The maternal-fetal transplacental passage can be influenced by the functional activity of P-glycoprotein [92]. Clinical studies reported that cyclosporine does not appear to be teratogenic $[93,94]$. The FDA classifies cyclosporine as category $\mathrm{C}$, meaning that human risk cannot be ruled out. No lingering effects due to breast-feeding have been found in infants who were breast-fed while their mothers were taking cyclosporine. Tacrolimus crosses the placenta with exposure in utero being approximately $71 \%$ of maternal blood concentrations. The lower fetal blood concentrations are likely due to active efflux transport of tacrolimus from the fetus toward the mother by placental P-glycoprotein [95]. In newborns from transplant recipients, the risk of major malformations was low. CNIs can cause both reversible nephrotoxicity and hyperkalemia in the newborn. In summary, in pregnant women, the fetal outcomes are not particularly influenced by CNIs. Large reviews of pregnant transplanted women taking CNIs showed that the fetal outcomes of transplanted patients were comparable with those of nontransplanted patients with similar levels of kidney function impairment [96]. The relatively large number of premature births that has been reported by some series may be partially explained by an obstetric policy favoring earlier delivery [97]. Nonetheless, long-term effects in humans prenatally exposed to CNIs require further evaluation.

Azathioprine (AZA) is an orally absorbed prodrug, being a modification of 6-mercaptopurine, which is an analogue of the purine basis hypoxanthine. Based on animal studies, the FDA classified AZA in class C, as a drug at potential risk of teratogenic effects. The human placenta is a relative barrier to 6-mercaptopurine and together with the poor fetal metabolism of 6-mercaptopurine can explain the lack of proven teratogenicity in humans [98]. A systematic review showed that the risk of congenital anomalies in offspring, as well as the infertility risk, are similar than those found in the general population; however, there is a higher incidence of prematurity, of lower weight at birth, and an intrauterine delay of development in AZA-treated pregnant women [99]. Thus, the use of AZA in pregnancy appears to be relatively safe.

Mammalian target of rapamycin (mTOR) inhibitors. Sirolimus and its derivate everolimus are two immunosuppressive drugs with similar chemical structure that inhibit the proliferation of $\mathrm{T}$ cells by interfering with a serine-threonine kinase, called mTOR [100]. According to the FDA, sirolimus and everolimus are classified in category C. Animal reproduction studies have shown an adverse effect on the fetus. There are no adequate and well-controlled studies in humans, but potential benefits may warrant use of the drug in pregnant women despite potential risks. Episodic reports of successful pregnancy outcomes with exposure to sirolimus [101,102] or everolimus [103-105] have been given on pregnant kidney transplant recipients.

Anti-thymocyte globulins (ATGs) are relatively safe medications with side effects mostly related to allergic reactions, nausea, vomiting, and diarrhea. There are no reports of fetal adverse events caused by ATG in humans. In an animal study, ATG caused decreased placental development in a murine model [106]. ATG has been successfully used to treat rejection in pregnant women [107].

Belatacept is a selective $\mathrm{T}$ cell costimulation blocker used to prevent rejection in organ transplantation. In animal studies, this drug, when given during organogenesis, was not teratogenic. Exposure to belatacept during pregnancy does not appear to be associated with an increased risk of birth defects Anecdotal cases of successful pregnancy and delivery with the use of belatacept-based immunosuppression have been reported [108,109].

\subsection{Drugs with Uncertain Safety}

Rituximab (RTX). Rituximab is a human/murine, chimeric anti-CD20 monoclonal antibody with established efficacy, and a favorable safety profile. RTX may cross the placenta and increase the risk of $\mathrm{B}$ cell depletion and other cytopenias in the neonate. According to the FDA, a teratogenic risk cannot be excluded for RTX (category C). Women may inadvertently become pregnant during or after RTX treatment. In a retrospective study, 
153 women with malignancy or autoimmune disease were given RTX during pregnancy. Of them, $90(59 \%)$ resulted in live births, and a high rate of miscarriages $(22 \%)$ was attributed to concomitant therapy. Two congenital malformations were identified [110]. In a systematic review of 102 pregnancies, no major safety signal was observed with RTX use within 6 months of conception [111]. The long-term effects of in utero exposure to RTX are unknown. There is agreement that the administration of RTX to a pregnant woman should be discouraged unless the benefits outweigh the potential risk for the fetus [112,113].

Eculizumab is a monoclonal antibody directed against complement protein 5. It is used in kidney transplantation to prevent and treat atypical HUS and antibody-mediated rejection. There is a selective transport of unbound eculizumab across the human placenta. The levels observed in umbilical cord blood samples do not affect the concentrations of complement in newborns [114]. There is little experience with the use of eculizumab in pregnant women. Most data come from pregnancies in women with paroxysmal nocturnal hemoglobinuria. In 75 pregnancies, there were no maternal deaths and three fetal deaths (4\%). Six miscarriages ( $8 \%$ ) occurred during the first trimester [115]. Theoretically, eculizumab may cause terminal complement inhibition in the fetal circulation. However, in a study on two newborns from mothers treated with eculizumab during pregnancy, the antibody neither accumulated in fetal plasma nor impaired the complement function in the newborn [116]. The drug should be administered to pregnant women only if benefits may justify the potentially increased risk for the fetus.

\subsection{Drugs with Fetal Toxicity}

Mycophenolate salts. Use of mycophenolate drugs during pregnancy is associated with an increased risk of first trimester pregnancy loss and increased risk of congenital malformations [117-119]. The FDA classifies these drugs as category D., i.e., with positive evidence of human fetal risk. It is recommended that pregnancy be avoided by women taking MPA. Women being considered for treatment with MPA should always have a negative pregnancy test and should employ at least two methods of contraception during its use [120-123]. If pregnancy occurs, mycophenolate should be stopped as early as possible. The later mycophenolate is discontinued, the higher is the risk of complications. Little information is available on the long-term effects in infants born to mothers who had been exposed to mycophenolate.

Bortezomib is a reversible inhibitor of the $26 \mathrm{~S}$ proteasome complex involved in degradation of ubiquitinated proteins. In kidney transplantation, bortezomib is used to prevent and treat antibody-mediated rejection. This drug has caused embryo-fetal lethality in animal studies at doses lower than the clinical dose. There are no controlled data in human pregnancy. Its use in pregnancy is not recommended.

Cyclophosphamide is rarely used in kidney transplantation. Its teratogenesis is well demonstrated in animals. The drug is mutagenic and can cause urogenital malformations including unilateral renal agenesis [124]. The gene mutations induced by cyclophosphamide are dose-dependent and cumulative. The drug is considered as class D by the FDA. Miscarriages and pre-term deliveries have been reported in mothers taking cyclophosphamide. Cases of malformation have been described in newborns of mothers who received cyclophosphamide in the first months of pregnancy. The drug is contraindicated in pregnancy, particularly in the first trimester $[125,126]$.

\subsection{Vaginal or Cesarean Delivery}

Cesarean section is frequently used to manage maternal issues, including poorly controlled diabetes, severe hypertension, and prolonged labor, or fetal disorders, such as malpresentation, non-reassuring heart rate, and growth restriction. However, a systematic review and meta-analysis reported that the complications related to Cesarean section in renal transplant recipients were $56.9 \%$, higher than the $31.9 \%$ in the general US population [35]. Normal vaginal delivery is probably the safest method of delivery in patients with kidney transplantation, and Cesarean section should be performed only for strict 
medical or obstetrical indications. Careful preparation for Cesarean section in renal transplant recipients is imperative. Providers should be aware of the anatomy of a transplanted kidney and vascular anastomosis. In the event of surgery, care should be taken to avoid injury to the ureter of the kidney allograft, which may be anterior to the uterine artery [127]. A transabdominal ultrasound should be performed to localize the kidney prior to surgery. A clear understanding of the anatomic changes after kidney transplantation can help decrease the risk of injury [128].

\section{Conclusions}

Pregnancy is not contraindicated in transplant women, but it should be planned with an obstetrician and nephrologist. Ideally, the patient should not become pregnant 1-2 years after transplantation and should have normal blood pressure and kidney function. The maternal risks include hypertension, preeclampsia, thrombotic microangiopathy, graft dysfunction, gestational diabetes, and infection. The main fetal risks include prematurity, low birth weight, and abortion, particularly in patients with poor graft function. Renin-angiotensin system inhibitors and some immunosuppressive agents, such as mycophenolate, bortezomib, and cyclophosphamide, are teratogenic and should not be prescribed to pregnant women. If these recommendations are respected, pregnancy can be considered a safe option in kidney transplant women.

Author Contributions: C.P. projected the study. B.Z. and G.M. reviewed and edited the study. All authors have read and agreed to the published version of the manuscript.

Funding: This manuscript was kindly funded by Franco Citterio, Department of Surgery, Kidney Transplantation, Catholic University, 00168, Rome, Italy.

Institutional Review Board Statement: Not applicable.

Informed Consent Statement: Not applicable.

Data Availability Statement: Data sharing not applicable. No new data were created or analyzed in this study.

Conflicts of Interest: The authors declare no conflict of interest.

\section{References}

1. Pezeshki, M.; Taherian, A.A.; Gharavy, M.; Ledger, W.L. Menstrual characteristics and pregnancy in women after renal transplantation. Int. J. Gynaecol. Obstet. 2004, 85, 119-125. [CrossRef]

2. Rao, S.; Ghanta, M.; Moritz, M.J.; Constantinescu, S. Long-Term Functional Recovery, Quality of Life, and Pregnancy After Solid Organ Transplantation. Med. Clin. N. Am. 2016, 100, 613-629. [CrossRef] [PubMed]

3. Sarkar, M.; Bramham, K.; Moritz, M.J.; Coscia, L. Reproductive health in women following abdominal organ transplant. Am. J. Transpl. 2018, 18, 1068-1076. [CrossRef] [PubMed]

4. Piccoli, G.B.; Cabiddu, G.; Attini, R.; Gerbino, M.; Todeschini, P.; Perrino, M.L.; Manzione, A.M.; Piredda, G.B.; Gnappi, E.; Caputo, F.; et al. Outcomes of Pregnancies After Kidney Transplantation: Lessons Learned From CKD. A Comparison of Transplanted, Nontransplanted Chronic Kidney Disease Patients and Low-Risk Pregnancies: A Multicenter Nationwide Analysis. Transplantation 2017, 101, 2536-2544. [CrossRef] [PubMed]

5. Shah, S.; Venkatesan, R.L.; Gupta, A.; Sanghavi, M.K.; Welge, J.; Johansen, R.; Kean, E.B.; Kaur, T.; Gupta, A.; Grant, T.J.; et al. Pregnancy outcomes in women with kidney transplant: Metaanalysis and systematic review. BMC Nephrol. 2019, $20,24$. [CrossRef] [PubMed]

6. Davison, J.M.; Baylis, C. Pregnancy in patients with underlying renal disease. In Oxford Textbook of Clinical Nephrology; Davison, A.M., Cameron, J.S., Grunfeld, J.P., Ponticelli, C., Ritz, E., Winearls, C.G., van Ypersele, C., Eds.; Oxford University Press: Oxford, UK, 2005; Volume 3, pp. 2243-2259.

7. McKay, D.B.; Josephson, M.A.; Armenti, V.T.; August, P.; Coscia, L.A.; Davis, C.L.; Davison, J.M.; Easterling, T.; Friedman, J.E.; Hou, S.; et al. Reproduction and transplantation: Report on the AST Consensus Conference on Reproductive Issues and Transplantation. Am. J. Transpl. 2005, 5, 1592-1599. [CrossRef]

8. Coscia, L.A.; Constantinescu, S.; Moritz, M.J.; Frank, A.M.; Ramirez, C.B.; Maley, W.R.; Doria, C.; McGrory, C.H.; Armenti, V.T. Report from the National Transplantation Pregnancy Registry (NTPR): Outcomes of pregnancy after transplantation. Clin. Transpl. 2010, 65-85.

9. Scheres, L.J.J.; Lijfering, W.M.; Groenewegen, N.F.M.; Koole, S.; de Groot, C.J.M.; Middeldorp, S.; Cannegieter, S.C. Hypertensive Complications of Pregnancy and Risk of Venous Thromboembolism. Hypertension 2020, 75, 781-787. [CrossRef] 
10. Stegeman, B.H.; de Bastos, M.; Rosendaal, F.R.; van Hylckama Vlieg, A.; Helmerhorst, F.M.; Stijnen, T.; Dekkers, O.M. Different combined oral contraceptives and the risk of venous thrombosis: Systematic review and network meta-analysis. BMJ 2013, 347, 5298. [CrossRef]

11. Paulen, M.E.; Folger, S.G.; Curtis, K.M.; Jamieson, D.J. Contraceptive use among solid organ transplant patients: A systematic review. Contraception 2010, 82, 102-112. [CrossRef]

12. Yousif, M.E.; Bridson, J.M.; Halawa, A. Contraception After Kidney Transplantation, From Myth to Reality: A Comprehensive Review of the Current Evidence. Exp. Clin. Transpl. 2016, 14, 252-258.

13. Huguelet, P.S.; Sheehan, C.; Spitzer, R.F.; Scott, S. Use of the levonorgestrel 52-mg intrauterine system in adolescent and young adult solid organ transplant recipients: A case series. Contraception 2017, 95, 378-381. [CrossRef] [PubMed]

14. Chandra, A.; Midtvedt, K.; Asberg, A.; Eide, I.A. Immunosuppression and Reproductive Health After Kidney Transplantation. Transplantation 2019, 103, e325-e333. [CrossRef] [PubMed]

15. Attini, R.; Cabiddu, G.; Montersino, B.; Gammaro, L.; Gernone, G.; Moroni, G.; Santoro, D.; Spotti, D.; Masturzo, B.; Gazzani, I.B.; et al. Contraception in chronic kidney disease: A best practice position statement by the Kidney and Pregnancy Group of the Italian Society of Nephrology. J. Nephrol. 2020, 33, 1343-1359. [CrossRef] [PubMed]

16. McKay, D.B.; Josephson, M.A. Pregnancy after transplantation. Clin. J. Am. Soc. Nephrol. 2008, 3 (Suppl. 2), S117-S125. [CrossRef] [PubMed]

17. Rose, C.; Gill, J.; Zalunardo, N.; Johnston, O.; Mehrotra, A.; Gill, J.S. Timing of pregnancy after kidney transplantation and risk of allograft failure. Am. J. Transpl. 2016, 16, 2360-2367. [CrossRef] [PubMed]

18. EBPG Expert Group on Renal Transplantation. European best practice guidelines for renal transplantation. Section IV: Long-term management of the transplant recipient. IV.10. Pregnancy in renal transplant recipients. Nephrol. Dial. Transpl. 2002, 17 (Suppl. 4), 50-55.

19. Davison, J.M.; Bailey, D.J. Pregnancy after transplantation. J. Obstet. Gynaecol. Res. 2003, 29, 227-233. [CrossRef]

20. Cabiddu, G.; Spotti, D.; Gernone, G.; Santoro, D.; Moroni, G.; Gregorini, G.; Giacchino, F.; Attini, R.; Limardo, M.; Gammaro, L.; et al. A best-practice position statement on pregnancy after kidney transplantation: Focusing on the unsolved questions. The Kidney and Pregnancy Study Group of the Italian Society of Nephrology. J. Nephrol. 2018, 31, 665-681. [CrossRef]

21. Danziger-Isakov, L.; Kumar, D. AST ID Community of Practice. Vaccination of solid organ transplant candidates and recipients: Guidelines from the American society of transplantation infectious diseases community of practice. Clin. Transpl. 2019, 33 , e13563. [CrossRef]

22. Zhu, L.; Gong, N.; Liu, B.; Lu, X.; Chen, D.; Chen, S.; Shu, H.; Ma, K.; Xu, X.; Guo, Z.; et al. Coronavirus Disease 2019 pneumonia in immunosuppressed renal transplant recipients: A summary of 10 confirmed cases in Wuhan China. Eur. Urol. 2020, 77, 748-754. [CrossRef]

23. Banerjee, D.; Popoola, J.; Shah, S.; Ster, I.C.; Quan, V.; Phanish, M. COVID-19 infection in kidney transplant recipients. Kidney Int. 2020, 97, 1076-1082. [CrossRef]

24. Alberici, F.; Delbarba, E.; Manenti, E.; Econimo, L.; Valerio, F.; Pola, A.; Maffei, C.; Possenti, S.; Zambetti, N.; Moscato, M.; et al. A single center observational study of the clinical characteristics and short-term outcome of 20 kidney transplant patients admitted for SARS-CoV2 pneumonia. Kidney Int. 2020, 97, 1083-1088. [CrossRef] [PubMed]

25. Caillard, S.; Chavarot, N.; Francois, H.; Matignon, M.; Greze, C.; Kamar, N.; Gatault, P.; Thaunat, O.; Legris, T.; Frimat, L.; et al. Is COVID-19 infection more severe in kidney transplant recipients? Am. J. Transpl. 2021, 21, 1295-1303. [CrossRef]

26. Tillett, R.L.; Sevinsky, J.R.; Hartley, P.D.; Kerwin, H.; Crawford, N.; Gorzalski, A.; Laverdure, C.; Verma, S.C.; Rossetto, C.C.; Jackson, D.; et al. Genomic evidence for reinfection with SARS-CoV-2: A case study. Lancet Infect. Dis. 2021, 21, 52-58. [CrossRef]

27. Piccoli, G.B.; Cabiddu, G.; Attini, R.; Vigotti, F.N.; Maxia, S.; Lepori, N.; Tuveri, M.; Massidda, M.; Marchi, C.; Mura, S.; et al. Risk of Adverse Pregnancy Outcomes in Women with CKD. J. Am. Soc. Nephrol. 2015, 26, 2011-2022. [CrossRef]

28. Mor, G.; Cardenas, I. The immune system in pregnancy: A unique complexity. Am. J. Reprod. Immunol. 2010, 63, 425-433. [CrossRef] [PubMed]

29. De Souza, R.M.; Olsburgh, J. Urinary tract infection in the renal transplant patient. Nat. Clin. Pract. Nephrol. 2008, 4, 252-264. [CrossRef]

30. Yan, L.; Jin, Y.; Hang, H.; Yan, B. The association between urinary tract infection during pregnancy and preeclampsia: A metaanalysis. Medicine 2018, 97, e12192. [CrossRef]

31. Leruez-Ville, M.; Foulon, I.; Pass, R.; Ville, Y. Cytomegalovirus infection during pregnancy: State of the science. Am. J. Obstet. Gynecol. 2020, 223, 330-349. [CrossRef] [PubMed]

32. Ponticelli, C.; Cucchiari, D.; Graziani, G. Hypertension in kidney transplant recipients. Transpl. Int. 2011, 24, 523-533. [CrossRef]

33. Rubin, M.F. Hypertension following kidney transplantation. Adv. Chronic Kidney Dis. 2011, 18, 17-22. [CrossRef] [PubMed]

34. Mastrobattista, J.M.; Gomez-Lobo, V. Society for Maternal-Fetal Medicine, authors. Pregnancy after solid organ transplantation. Obstet. Gynecol. 2008, 112, 919-932. [CrossRef] [PubMed]

35. Deshpande, N.A.; James, N.T.; Kucirka, L.M.; Boyarsky, B.J.; Garonzik-Wang, J.M.; Montgomery, R.A.; Segev, D.L. Pregnancy outcomes in kidney transplant recipients: A systematic review and meta-analysis. Am. J. Transplant. 2011, 11, 2388-2404. [CrossRef]

36. Magee, L.; von Dadelszen, P. State-of-the art diagnosis and treatment of hypertension in pregnancy. Mayo Clin. Proc. 2018, 93, 1664-1677. [CrossRef] [PubMed] 
37. Firoz, T.; Magee, L.A.; MacDonell, K.; Payne, B.A.; Gordon, R.; Vidler, M.; von Dadelszen, P. Community Level Interventions for Pre-eclampsia (CLIP) Working Group. Oral antihypertensive therapy for severe hypertension in pregnancy and postpartum: A systematic review. BJOG 2014, 121, 1210-1218. [CrossRef]

38. Buawangpong, N.; Teekachunhatean, S.; Koonrungsesomboon, N. Adverse pregnancy outcomes associated with first-trimester exposure to angiotensin-converting enzyme inhibitors or angiotensin II receptor blockers: A systematic review and meta-analysis. Pharmacol. Res. Perspect. 2020, 8, e00644. [CrossRef]

39. Fu, J.; Tomlinson, G.; Feig, D.S. Early Pregnancy Exposure to Angiotensin-Converting-Enzyme Inhibitors and Angiotensin Receptor Blockers Associated with Congenital Malformations and Stillbirths: A Systematic Review and Meta-analysis. Diabetes Metab. Res. Rev. 2021. online ahead of print. [CrossRef]

40. Majak, G.B.; Sandven, I.; Lorentzen, B.; Vangen, S.; Reisaeter, A.V.; Henriksen, T.; Michelsen, T.M. Pregnancy outcomes following maternal kidney transplantation: A national cohort study. Acta Obstet. Gynecol. Scand. 2016, 95, 1153-1161. [CrossRef]

41. Josephson, M.A.; McKay, D.B. Pregnancy and kidney transplantation. Semin. Nephrol. 2011, 31, 100-110. [CrossRef]

42. Phipps, E.; Prasanna, D.; Brima, W.; Jim, B. Preeclampsia updates in pathogenesis, definitions and gudelines. Clin. J. Am. Soc. Nephrol. 2016, 11, 1102-1113. [CrossRef]

43. Schuster, J.; Cheng, S.B.; Padbury, J.; Sharma, S. Placental extracellular vesicles and pre-eclampsia. Am. J. Reprod. Immunol. 2021, 85, e13297. [CrossRef]

44. Bandoli, G.; Palmsten, K.; Forbess Smith, C.J.; Chambers, C.D. A review of systemic corticosteroid use in pregnancy and the risk of select pregnancy and birth outcome. Rheum. Dis. Clin. N. Am. 2017, 43, 489-502. [CrossRef]

45. Chakravarty, E.F.; Colón, I.; Langen, E.S.; Nix, D.A.; El-Sayed, Y.Y.; Genovese, M.C.; Druzin, M.L. Factors that predict prematurity and preeclampsia in pregnancies that are complicated by systemic lupus erythematosus. Am. J. Obstet. Gynecol. 2005, 192, 1897-1904. [CrossRef]

46. Boyd, H.A.; Basit, S.; Harpsøe, M.C.; Wohlfahrt, J.; Jess, T. Inflammatory Bowel Disease and Risk of Adverse Pregnancy Outcomes. PLoS ONE 2015, 10, e0129567. [CrossRef]

47. Palmsten, K.; Hernández-Diaz, S.; Kuriya, B.; Solomon, D.H.; Setoguchi, S. Use of Disease-Modifying Antirheumatic Drugs During Pregnancy and Risk of Preeclampsia. Arthritis Care Res. 2012, 64, 1730-1738. [CrossRef]

48. Paziana, K.; Del Monaco, M.; Cardonick, E.; Moritz, M.; Keller, M.; Smith, B.; Coscia, L.; Armenti, V. Ciclosporin use during pregnancy. Drug Saf. 2013, 36, 279-294. [CrossRef]

49. Le, H.L.; Francke, M.I.; Andrews, L.M.; de Winter, B.C.M.; van Gelder, T.; Hesselink, D.A. Usage of Tacrolimus and Mycophenolic Acid During Conception, Pregnancy, and Lactation, and Its Implications for Therapeutic Drug Monitoring: A Systematic Critical Review. Ther. Drug Monit. 2020, 42, 518-531. [CrossRef] [PubMed]

50. Gong, X.; Li, J.; Yan, J.; Dai, R.; Liu, L.; Chen, P.; Chen, X. Pregnancy outcomes in female patients exposed to cyclosporin-based versus tacrolimus-based immunosuppressive regimens after liver/kidney transplantation: A systematic review and meta-analysis. J. Clin. Pharm. Ther. 2021, 46, 744-753. [CrossRef] [PubMed]

51. Majak, G.B.; Reisæter, A.V.; Zucknick, M.; Lorentzen, B.; Vangen, S.; Henriksen, T.; Michelsen, T.M. Preeclampsia in kidney transplanted women; Outcomes and a simple prognostic risk score system. PLoS ONE 2017, 12, e0173420.

52. Shah, P.B.; Samra, M.; Josephson, M.A. Preeclampsia risk in kidney donors and recipients. Curr. Hypertens. Rep. 2018, 20, 59. [CrossRef]

53. Vannevel, V.; Claes, K.; Baud, D.; Vial, Y.; Golshayan, D.; Yoon, E.W.; Hodges, R.; Le Nepveu, A.; Kerr, P.G.; Kennedy, C.; et al. Preeclampsia and Long-term Renal Function in Women Who Underwent Kidney Transplantation. Obstet Gynecol. 2018, 131, 57-62. [CrossRef]

54. Lucas, M.J.; Leveno, K.J.; Cunningham, F.G. A comparison of magnesium sulfate with phenytoin for the prevention of eclampsia. N. Engl. J. Med. 1995, 333, 201-205. [CrossRef]

55. Saccone, G.; Berghella, V. Antenatal corticosteroids for maturity of term or nearterm fetuses: A systematic review and metaanalysis of randomized controlled trials. BMJ 2016, 355, i5044. [CrossRef]

56. Gupta, M.; Feinberg, B.B.; Burwick, R.M. Thrombotic microangiopathies of pregnancy: Differential diagnosis. Pregnancy Hypertens. 2018, 12, 29-34. [CrossRef] [PubMed]

57. Fakhouri, F.; Scully, M.; Provôt, F.; Blasco, M.; Coppo, P.; Noris, M.; Paizis, K.; Kavanagh, D.; Pène, F.; Quezada, S.; et al. Management of thrombotic microangiopathy in pregnancy and postpartum: Report from an international working group. Blood 2020, 136, 2103-2117. [CrossRef] [PubMed]

58. Saad, A.F.; Roman, J.; Wyble, A.; Pacheco, L.D. Pregnancy-Associated Atypical Hemolytic-Uremic Syndrome. AJP Rep. 2016, 6, e125-e128. [PubMed]

59. Bruel, A.; Kavanagh, D.; Noris, M.; Delmas, Y.; Wong, E.K.S.; Bresin, E.; Provôt, F.; Brocklebank, V.; Mele, C.; Remuzzi, G.; et al. Hemolytic Uremic Syndrome in Pregnancy and Postpartum. Clin. J. Am. Soc. Nephrol. 2017, 12, 1237-1247. [CrossRef]

60. Dines, V.; D'Costa, M.; Fidler, M.; Kattah, A. The role of kidney biopsy in diagnosis of preeclampsia in kidney transplant patients. Hypertens. Pregnancy 2020, 39, 418-422. [CrossRef]

61. Kim, H.; Jeong, J.C.; Yang, J.; Yang, W.S.; Ahn, C.; Han, D.J.; Park, J.S.; Park, S.K. The optimal therapy of calcineurin inhibitors for pregnancy in kidney transplantation. Clin. Transplant. 2015, 29, 142-148. [CrossRef]

62. Naesens, M.; Kuypers, D.R.; Sarwal, M. Calcineurin inhibitor nephrotoxicity. Clin. J. Am. Soc. Nephrol. 2009, 4, 481-508. [CrossRef]

63. Epidis, K. Pregnancy in women with renal disease. Yes or no? Hippokratia 2011, 15 (Suppl. 1), 8-12. 
64. HAPO Study Cooperative Research Group; Metzger, B.E.; Lowe, L.P.; Dyer, A.R.; Trimble, E.R.; Chaovarindr, U.; Coustan, D.R.; Hadden, D.R.; McCance, D.R.; Hod, M.; et al. Hyperglycemia and adverse pregnancy outcomes. N. Engl. J. Med. 2008, 358, 1991-2002.

65. Catalano, P.M.; McIntyre, H.D.; Cruickshank, J.K.; McCance, D.R.; Dyer, A.R.; Metzger, B.E.; Lowe, L.P.; Trimble, E.R.; Coustan, D.R.; Hadden, D.R.; et al. The hyperglycemia and adverse pregnancy outcome study: Associations of GDM and obesity with pregnancy outcomes. Diabetes Care 2012, 35, 780-786. [CrossRef] [PubMed]

66. Waters, T.P.; Dyer, A.R.; Scholtens, D.M.; Dooley, S.L.; Herer, E.; Lowe, L.P.; Oats, J.J.; Persson, B.; Sacks, D.A.; Metzger, B.E.; et al. Maternal and Neonatal Morbidity for Women Who Would Be Added to the Diagnosis of GDM Using IADPSG Criteria: A Secondary Analysis of the Hyperglycemia and Adverse Pregnancy Outcome Study. Diabetes Care 2016, 39, 2204-2210. [CrossRef]

67. Coustan, D.R.; Lowe, L.P.; Metzger, B.E. The hyperglycemia and adverse pregnancy outcome (HAPO) study: Can we use the results as a basis for change? J. Matern. Fetal Neonatal Med. 2010, 23, 204-209. [CrossRef] [PubMed]

68. Lende, M.; Rijhsinghani, A. Gestational Diabetes: Overview with Emphasis on Medical Management. Int. J. Environ. Res. Public Health 2020, 17, 9573. [CrossRef] [PubMed]

69. Yildirim, Y.; Uslu, A. Pregnancy in patients with previous successful renal transplantation. Int. J. Gynaecol. Obstet. 2005, 90, 198-202. [CrossRef]

70. Sturgiss, S.N.; Davison, J.M. Effect of pregnancy on the long-term function of renal allografts. An update. Am. J. Kidney Dis. 1995, 26, 54-56. [CrossRef]

71. Fischer, T.; Neumayer, H.H.; Fischer, R.; Barenbrock, M.; Schobel, H.P.; Lattrell, B.C.; Jacobs, V.R.; Paepke, S.; Pildner von Steinburg, S.; Schmalfeldt, B.; et al. Effect of pregnancy on long-term kidney function in renal transplant recipients treated with cyclosporine and with azathioprine. Am. J. Transplant. 2005, 5, 2732-2739. [CrossRef]

72. Rahamimov, R.; Ben-Haroush, A.; Wittenberg, C.; Mor, E.; Lustig, S.; Gafter, U.; Hod, M.; Bar, J. Pregnancy in renal transplant recipients: Long-term effect on patient and graft survival. A single-center experience. Transplantation 2006, 81, 660-664. [CrossRef] [PubMed]

73. Ghanem, M.E.; El-Baghdadi, L.A.; Badawy, A.M.; Bakr, M.A.; Sobhe, M.A.; Ghoneim, M.A. Pregnancy outcome after renal allograft transplantation: 15 years' experience. Eur. J. Obstet. Gynecol. Reprod. Biol. 2005, 121, 178-181. [CrossRef] [PubMed]

74. Levidiotis, V.; Chang, S.; McDonald, S. Pregnancy and maternal outcomes among kidney transplant recipients. J. Am. Soc. Nephrol. 2009, 20, 2433-2440. [CrossRef] [PubMed]

75. Van Buren, M.C.; Schellekens, A.; Groenhof, T.K.J.; van Reekum, F.; van de Wetering, J.; Paauw, N.D.; Lely, A.T. Long-term Graft Survival and Graft Function Following Pregnancy in Kidney Transplant Recipients: A Systematic Review and Meta-analysis. Transplantation 2020, 104, 1675-1685. [CrossRef]

76. Thompson, B.C.; Kingdon, E.J.; Tuck, S.M.; Fernando, O.N.; Sweny, P. Pregnancy in renal transplant recipients: The Royal Free Hospital experience. QJM 2003, 96, 837-844. [CrossRef]

77. You, J.Y.; Kim, M.K.; Choi, S.J.; Oh, S.Y.; Kim, S.J.; Kim, J.H.; Oh, H.Y.; Roh, C.R. Predictive factors for adverse pregnancy outcomes after renal transplantation. Clin. Transplant. 2014, 28, 699-706. [CrossRef]

78. Covella, B.; Vinturache, A.E.; Cabiddu, G.; Attini, R.; Gesualdo, L.; Versino, E.; Piccoli, G.B. A systematic review and meta-analysis indicate long-term risk of chronic and end-stage kidney disease after preeclampsia. Kidney Int. 2019, 96, 711-727. [CrossRef]

79. Solano, M.E.; Arck, P.C. Steroids, pregnancy and fetal development. Front. Immunol. 2020, 10, 3017. [CrossRef]

80. Levitz, M.; Jansen, V.; Dancis, J. The transfer and metabolism of corticosteroids in the perfused human placenta. Am. J. Obstet. Gynecol. 1978, 132, 363-366. [CrossRef]

81. Brown, R.W.; Chapman, K.E.; Edwards, C.R.; Seckl, J.R. Human placental 11 beta-hydroxysteroid dehydrogenase: Evidence for and partial purification of a distinct NAD-dependent isoform. Endocrinology 1993, 132, 2614-2621. [CrossRef]

82. Busada, J.T.; Cidlowski, J.A. Mechanisms of glucocorticoid action during development. Curr. Top. Dev. Biol. 2017, 125, 147-170.

83. Goedhart, G.; Vrijkotte, T.G.; Roseboom, T.J.; van der Wal, M.F.; Cuijpers, P.; Bonsel, G.J. Maternal cortisol and offspring birthweight: Results from a large prospective cohort study. Psychoneuroendocrinology 2010, 35, 644-652. [CrossRef]

84. Bloom, S.L.; Sheffield, J.S.; McIntire DDLeveno, K.J. Antenatal dexamethasone and decreased birth weight. Obstet. Gynecol. 2001, 97, 485-490.

85. Reynolds, R.M. Programming effects of glucocorticoids. Clin. Obstet. Gynecol. 2013, 56, 602-609. [CrossRef]

86. Moisiadis, V.G.; Matthews, S.G. Glucocorticoids and fetal programming part 1: Outcomes. Nat. Rev. Endocrinol. 2014, 10, $391-402$. [CrossRef]

87. McCalla, C.; Nacharaju, V.L.; Muneyyirci-Delale, O.; Glasgow, S.; Feldman, J.G. Placental 11 $\beta$-hydroxysteroid dehydrogenase activity in normotensive and pre-eclamptic pregnancies. Steroids 1998, 63, 511-515. [CrossRef]

88. Chambers, C.D.; Tutuncu, Z.N.; Johnson, D.; Jones, K.L. Human pregnancy safety for agents used to treat rheumatoid arthritis: Adequacy of available information and strategies for developing post-marketing data. Arthritis Res. Ther. 2006, 8, 215. [CrossRef]

89. Bay Bjørn, A.M.; Ehrenstein, V.; Hundborg, H.H.; Nohr, E.A.; Sørensen, H.T.; Nørgaard, M. Use of corticosteroids in early pregnancy is not associated with risk of oral clefts and other congenital malformations in offspring. Am. J. Ther. 2014, 21, 73-80. [CrossRef] [PubMed]

90. Armenti, V.T. Pregnancy after transplantation. Milestones and assessment of risk. Am. J. Transpl. 2011, 11, 2275-2276. [CrossRef] [PubMed] 
91. Venkataramanan, R.; Koneru, B.; Wang, C.C.; Burckart, G.J.; Caritis, S.N.; Starzl, T.E. Cyclosporine and its metabolites in mother and baby. Transplantation 1988, 46, 468-469. [CrossRef] [PubMed]

92. Pávek, P.; Fendrich, Z.; Staud, F.; Malákova, J.; Brozmanová, H.; Láznícek, M.; Semecký, V.; Grundmann, M.; Palicka, V. Influence of P-glycoprotein on the transplacental passage of cyclosporine. J. Pharm. Sci. 2001, 90, 1583-1592. [CrossRef] [PubMed]

93. Janssen, N.M.; Genta, M.S. The effects of immunosuppressive and anti-inflammatory medications on fertility, pregnancy and lactation. Arch. Intern. Med. 2000, 160, 610-619. [CrossRef] [PubMed]

94. Gotestam Skorpen, C.; Hoeltzenbein, M.; Tincani, A.; Fischer-Betz, R.; Elefante, E.; Chambers, C.; da Silva, J.; Nelson-Piercy, C.; Cetin, I.; Costedoat-Chalumeau, N.; et al. The EULAR points to consider for use of antirheumatic drugs before pregnancy, and during pregnancy and lactation. Ann. Rheum. Dis. 2016, 75, 795-810. [CrossRef] [PubMed]

95. Hebert, M.F.; Zheng, S.; Hays, K.; Shen, D.D.; Davis, C.L.; Umans, J.G.; Miodovnik, M.; Thummel, K.E.; Easterling, T.R. Interpreting tacrolimus concentrations during pregnancy and postpartum. Transplantation 2013, 95, 908-915. [CrossRef]

96. Sibanda, N.; Briggs, J.D.; Davison, J.M.; Johnson, R.J.; Rudge, C.J. Pregnancy after organ transplantation: A report from the UK Transplant Pregnancy Registry. Transplantation 2007, 83, 1301-1307. [CrossRef]

97. Piccoli, G.B.; Cabiddu, G.; Attini, R.; Gerbino, M.; Todeschini, P.; Perrino, M.L.; Manzione, A.M.; Piredda, G.B.; Gnappi, E.; Caputo, F.; et al. Pregnancy outcomes after kidney graft in Italy: Are the changes over time the result of different therapies or of different policies? A nationwide survey (1978-2013). Nephrol. Dial. Transpl. 2016, 31, 1957-1965. [CrossRef]

98. Hutson, J.R.; Lubetsky, A.; Walfisch, A.; Ballios, B.G.; Garcia-Bournissen, F.; Koren, G. The transfer of 6-mercaptopurine in the dually perfused human placenta. Reprod. Toxicol. 2011, 32, 349-353. [CrossRef] [PubMed]

99. Belizna, C.; Meroni, P.L.; Shoenfeld, Y.; Devreese, K.; Alijotas-Reig, J.; Esteve-Valverde, E.; Chighizola, C.; Pregnolato, F.; Cohen, H.; Fassot, C.; et al. In utero exposure to Azathioprine in autoimmune disease. Where do we stand? Autoimmun. Rev. 2020, 19, 102925. [CrossRef]

100. Ponticelli, C. The pros and cons of mTOR inhibitors in kidney transplantation. Expert Rev. Clin. Immunol. 2014, 10, 295-305. [CrossRef]

101. Chu, S.H.; Liu, K.L.; Chiang, Y.J.; Wang, H.H.; Lai, P.C. Sirolimus used during pregnancy in a living related renal transplant recipient: A case report. Transpl. Proc. 2008, 40, 2446-2448. [CrossRef]

102. Framarino dei Malatesta, M.; Corona, L.E.; De Luca, L.; Rocca, B.; Maria Manzia, T.; Orlando, G.; Tisone, G.; Iaria, G. Successful pregnancy in a living-related kidney transplant recipient who received sirolimus throughout the whole gestation. Transplantation 2011, 91, e69-e71. [CrossRef] [PubMed]

103. Yamamura, M.; Kojima, T.; Koyama, M.; Sazawa, A.; Yamada, T.; Minakami, H. Everolimus in pregnancy: Case report and literature review. J. Obstet. Gynaecol. Res. 2017, 43, 1350-1352. [CrossRef] [PubMed]

104. Veroux, M.; Corona, D.; Veroux, P. Pregnancy under everolimus-based immunosuppression. Transpl. Int. 2011, 24, e115-e117. [CrossRef] [PubMed]

105. Margoles, H.R.; Gomez-Lobo, V.; Veis, J.H.; Sherman, M.J.; Moore, J., Jr. Successful maternal and fetal outcome in a kidney transplant patient with everolimus exposure throughout pregnancy: A case report. Transpl. Proc. 2014, 46, 281-283. [CrossRef] [PubMed]

106. Athanassakis, I.; Chaouat, G.; Wegmann, T.G. The effects of anti-CD4 and anti-CD8 antibody treatment on placental growth and function in allogeneic and syngeneic murine pregnancy. Cell. Immunol. 1990, 129, 13-21. [CrossRef]

107. Kutzler, H.L.; Ye, X.; Rochon, C.; Martin, S.T. Administration of Antithymocyte Globulin (Rabbit) to Treat a Severe, Mixed Rejection Episode in a Pregnant Renal Transplant Recipient. Pharmacotherapy 2016, 36, e18-e22. [CrossRef]

108. Combs, J.; Kagan, A.; Boelkins, M.; Coscia, L.; Moritz, M.; Hoffmann, R.M. Belatacept during pregnancy in renal transplant recipients: Two case reports. Am. J. Transpl. 2018, 18, 2079-2082. [CrossRef]

109. Klintmalm, G.B.; Gunby, R.T., Jr. Successful Pregnancy in a Liver Transplant Recipient on Belatacept. Liver Transpl. 2020, 26, 1193-1194. [CrossRef]

110. Chakravarty, E.F.; Murray, E.R.; Kelman, A.; Farmer, P. Pregnancy outcomes after maternal exposure to rituximab. Blood 2011, 117, 1499-1506. [CrossRef]

111. Das, G.; Damotte, V.; Gelfand, J.M.; Bevan, C.; Cree, B.A.C.; Do, L.; Green, A.J.; Hauser, S.L.; Bove, R. Rituximab before and during pregnancy: A systematic review, and a case series in MS and NMOSD. Neurol. Neuroimmunol. Neuroinflamm. 2018, 19, e453. [CrossRef]

112. Ostensen, M. Safety issues of biologics in pregnant patients with rheumatic diseases. Ann. N. Y. Acad. Sci. 2014, 1317, 32-38. [CrossRef]

113. Levy, R.A.; de Jesús, G.R.; de Jesús, N.R.; Klumb, E.M. Critical review of the current recommendations for the treatment of systemic inflammatory rheumatic diseases during pregnancy and lactation. Autoimmun. Rev. 2016, 15, 955-963. [CrossRef]

114. Hallstensen, R.F.; Bergseth, G.; Foss, S.; Jæger, S.; Gedde-Dahl, T.; Holt, J.; Christiansen, D.; Lau, C.; Brekke, O.L.; Armstrong, E.; et al. Eculizumab treatment during pregnancy does not affect the complement system activity of the newborn. Immunobiology 2015, 220, 452-459. [CrossRef]

115. Kelly, R.J.; Höchsmann, B.; Szer, J.; Kulasekararaj, A.; de Guibert, S.; Röth, A.; Weitz, I.C.; Armstrong, E.; Risitano, A.M.; Patriquin, C.J.; et al. Eculizumab in Pregnant Patients with Paroxysmal Nocturnal Hemoglobinuria. N. Engl. J. Med. 2015, 373, 1032-1039. [CrossRef] [PubMed] 
116. Sarno, L.; Tufano, A.; Maruotti, G.M. Eculizumab in pregnancy: A narrative review. J. Nephrol. 2019, 32, 17-25. [CrossRef] [PubMed]

117. Hoeltzenbein, M.; Elefant, E.; Vial, T.; Finkel-Pekarsky, V.; Stephens, S.; Clementi, M.; Allignol, A.; Weber-Schoendorfer, C.; Schaefer, C. Teratogenicity of mycophenolate confirmed in a prospective study of the European Network of Teratology Information Services. Am. J. Med. Genet. A 2012, 58, 588-596. [CrossRef] [PubMed]

118. Martín, M.C.; Cristiano, E.; Villanueva, M.; Bonora, M.L.; Berguio, N.; Tocci, A.; Groisman, B.; Bidondo, M.P.; Liascovich, R.; Barbero, P. Esophageal atresia and prenatal exposure to mycophenolate. Reprod. Toxicol. 2014, 50, 117-121. [CrossRef]

119. Coscia, L.A.; Armenti, D.; King, R.W.; Sifontis, N.M.; Constantinescu, S.; Moritz, M.J. Update on the Teratogenicity of Maternal Mycophenolate Mofetil. J. Pediatr. Genet. 2015, 4, 42-55.

120. Klieger-Grossmann, C.; Chitayat, D.; Lavign, S.; Kao, K.; Garcia-Bournissen, F.; Quinn, D.; Luo, V.; Sermer, M.; Riordan, S.; Laskin, C.; et al. Prenatal exposure to mycophenolate mofetil: An updated estimate. J. Obstet. Gynaecol. Can. 2010, 32, 794-797. [CrossRef]

121. Kylat, R.I. What is the teratogenic risk of mycophenolate? J. Pediatr. Genet. 2017, 6, 111-114. [CrossRef]

122. King, R.W.; Baca, M.J.; Armenti, V.T.; Kaplan, B. Pregnancy Outcomes Related to Mycophenolate Exposure in Female Kidney Transplant Recipients. Am. J. Transpl. 2017, 17, 151-160. [CrossRef] [PubMed]

123. Colla, L.; Diena, D.; Rossetti, M.; Manzione, A.M.; Marozio, L.; Benedetto, C.; Biancone, L. Immunosuppression in pregnant women with renal disease: Review of the latest evidence in the biologic's era. J. Nephrol. 2018, 31, 361-383. [CrossRef] [PubMed]

124. Kirshon, B.; Wasserstrum, N.; Willis, R.; Herman, G.E.; McCabe, E.R. Teratogenic effects of first-trimester cyclophosphamide therapy. Obstet. Gynecol. 1988, 72, 462-464. [PubMed]

125. Grijalva-Flores, J.; Guerrero-Romero, F. Klippel-Feil syndrome in a boy exposed inadvertently to cyclophosphamide during pregnancy: A case report. Birth Defects Res. A Clin. Mol. Teratol. 2012, 94, 249-252.

126. Rengasamy, P. Congenital Malformations Attributed to Prenatal Exposure to Cyclophosphamide. Anticancer Agents Med. Chem. 2017, 17, 1211-1227. [CrossRef] [PubMed]

127. Ong, S.C.; Kumar, V. Pregnancy in a kidney transplant patient. Clin. J. Am. Soc. Nephrol. 2020, 15, 120-122. [CrossRef]

128. Gordon, C.E.; Tatsis, V. Shearing-force injury of a kidney transplant graft during cesarean section: A case report and review of the literature. BMC Nephrol. 2019, 20, 1852. [CrossRef] 